\title{
Therapeutic vaccination and immunomodulation in the treatment of chronic hepatitis B: preclinical studies in the woodchuck
}

\author{
Anna D. Kosinska $\cdot$ Jia Liu $\cdot$ Mengji Lu $\cdot$ \\ Michael Roggendorf
}

Received: 13 July 2014 / Accepted: 18 September 2014 / Published online: 23 December 2014

(C) The Author(s) 2014. This article is published with open access at Springerlink.com

\begin{abstract}
Infection with hepatitis B virus (HBV) may lead to subclinical, acute or chronic hepatitis. In the prevaccination era, HBV infections were endemic due to frequent mother to child transmission in large regions of the world. However, there are still estimated 240 million chronic HBV carriers today and ca. 620,000 patients die per year due to HBV-related liver diseases. Recommended treatment of chronic hepatitis B with interferon- $\alpha$ and/ or nucleos(t)ide analogues does not lead to satisfactory results. Induction of $\mathrm{HBV}$-specific $\mathrm{T}$ cells by therapeutic vaccination or immunomodulation may be an innovative strategy to overcome virus persistence. Vaccination with commercially available HBV vaccines in patients with or without therapeutic reduction of viral load did not result in effective immune control of HBV infection, suggesting that combination of antiviral treatment with new formulations of therapeutic vaccines is needed. The woodchuck (Marmota monax) and its HBV-like woodchuck hepatitis virus are a useful preclinical animal model for developing new therapeutic approaches in chronic hepadnaviral infections. Several innovative approaches combining antiviral treatments using nucleos(t)ide analogues, with primeboost vaccination using DNA vaccines, new hepadnaviral antigens or recombinant adenoviral vectors were tested in the woodchuck model. In this review, we summarize these encouraging results obtained with these therapeutic vaccines. In addition, we present potential innovations
\end{abstract}

This article is part of the special issue "Therapeutic vaccination in chronic hepatitis B-approaches, problems and new perspectives".

A. D. Kosinska $\cdot$ J. Liu $\cdot$ M. Lu $\cdot$ M. Roggendorf $(\square)$ Institute for Virology, University Hospital of Essen, University of Duisburg-Essen, Virchowstrasse 179, 45122 Essen, Germany e-mail: michael.roggendorf@uni-due.de in immunostimulatory strategies by blocking the interaction of the inhibitory programmed death receptor 1 with its ligand in this animal model.

Keywords Chronic hepatitis B · Hepatitis B virus · Woodchuck hepatitis virus · Immunotherapy $\cdot$ Gene therapy $\cdot$ Therapeutic vaccination $\cdot$ Immunomodulation

\section{Introduction}

More than 240 million people worldwide are persistently infected with hepatitis B virus (HBV) and are at risk of developing chronic liver disease, cirrhosis and hepatocellular carcinoma (HCC) [1]. An effective and affordable therapy to achieve sustained suppression of HBV replication and remission of liver disease is urgently needed. Pegylated interferon-alpha $2 \mathrm{a}(\mathrm{IFN}-\mathrm{a})$ is recommended for the treatment of chronic hepatitis B (CHB) in the current consensus guidelines of many countries. Compared with conventional recombinant IFN-a, however, pegylated IFN-a alone or in combination with nucleoside analogues does not significantly increase the rate of sustained response [2, 3]. Nucleos(t)ide analogues, such as, entecavir and tenofovir, suppress HBV replication and result in the improvement of liver architecture. However, these agents cannot eradicate HBV genomes from the liver and may further limited by the development increasingly select drug-resistant mutants with prolonged use [4, 5]. Therapy with additional antiviral drugs targeting other steps in the viral life cycle, in combination with immunomodulatory options, might be more beneficial and effective.

More than $90 \%$ of acutely infected adults resolve clinical symptoms and maintain lifelong protective immunity by mounting a vigorous, multi-specific immune response 
to HBV proteins. By contrast, patients with chronic hepatitis B tend to have delayed, transient or narrowly focused T cell responses [6-8]. Patients who spontaneously recover from HBV infection might experience reactivation of HBV under immunosuppressive treatments. Thus, the specific immune responses to HBV remain crucial for the long-term control of HBV infection even after resolution of the acute infection. For chronically infected patients, immunostimulatory and immunomodulatory strategies to boost or to broaden the weak virus-specific $\mathrm{T}$ cell response have been proposed to reach an effective control of viral infection.

\section{Therapeutic vaccination studies in patients with chronic hepatitis B}

Since more than 20 years, numerous clinical trials exploited the conventional prophylactic vaccine based on the hepatitis B surface antigen (HBsAg) for therapeutic vaccination (Table 1). These studies demonstrated reductions in viremia, seroconversion of the hepatitis B "e" antigen (HBeAg) to anti-HBe and HBV-specific T cell responses in some patients after vaccination. However, the antiviral effect was only transient and did not lead to an effective control of the HBV [9-17].

A more sophisticated therapeutic vaccination based on HBsAg complexed with human anti-HBs was proposed by the group of Wen et al. [18]. Immunogenic complexes (IC) stimulate robust $\mathrm{T}$ cell responses by increasing uptake of
HBsAg through $\mathrm{Fc}$ receptors on antigen-presenting cells (APC) and, therefore, enhance HBsAg processing and presentation. It was demonstrated that this vaccine administered to $\mathrm{HBeAg}$-positive patients led to decrease of HBV DNA in serum and $\mathrm{HBeAg}$ seroconversion in some subjects [19]. In a phase II B clinical trial, $\mathrm{HBeAg}$ seroconversion was observed in about $21.6 \%$ of treated patients. Moreover, a moderate decrease in serum HBV DNA and HBsAg levels was observed after treatment [20,21]. Very recently, a large phase III clinical trial with 12 injections of IC complex failed to show any therapeutic efficacy when compared to the placebo control injected only with alum [22]. Overstimulation with IC-based vaccine did not increase but decreased efficacy of the therapeutic vaccination. These results underline that an appropriate immunization protocol is crucial for the efficacy of therapeutic vaccination.

DNA vaccines using plasmids expressing viral proteins have gained popularity given their ability to induce strong cellular and humoral immune responses. Several phase I clinical studies investigated the therapeutic efficacy of plasmid DNA vaccines expressing $\mathrm{HBsAg}$ in chronic HBV carriers. These studies showed evidence for the safety of HBV DNA vaccination (for details see below), but $\mathrm{T}$ cell responses were restored or activated at only a low level. Furthermore, DNA vaccines expressing only HBsAg did not result in significant suppression of viremia in chronic carriers of HBV [23, 24].

From results of these studies, it can be concluded that the therapeutic vaccination alone is not sufficient to achieve

Table 1 Therapeutic vaccination studies in patients with chronic hepatitis B using the conventional HBsAg vaccine, immune complexes, T cell vaccines and combination therapy

\begin{tabular}{|c|c|c|c|}
\hline Vaccination strategy & Vaccine & Antigen & References \\
\hline \multirow[t]{3}{*}{ Protein vaccine } & \multirow[t]{2}{*}{ Licensed HBsAg vaccine for prophylactic use } & Pre-S2/S & $\begin{array}{l}\text { Pol et al. }[13,14] \\
\text { Coullin et al. [9] } \\
\text { Ren et al. [15] } \\
\text { Yalcin et al. [17] } \\
\text { Dikici et al. [11] }\end{array}$ \\
\hline & & Pre-S1/pre-S2/S & $\begin{array}{l}\text { Jung et al. [12] } \\
\text { Safadi et al. [16] }\end{array}$ \\
\hline & Immune complexes of $\mathrm{HBsAg}-$ anti-HBs & $\mathrm{S}$ & $\begin{array}{l}\text { Wen et al. [18] } \\
\text { Yao et al. [19] } \\
\text { Xu et al. [21] } \\
\text { Xu et al. [22] }\end{array}$ \\
\hline \multirow[t]{2}{*}{$\mathrm{T}$ cell vaccine } & CTL-peptide vaccine & $\mathrm{HBcAg}$ & Heathcote et al. [112] \\
\hline & DNA vaccine (HBsAg) & Pre-S2/S & Mancini-Bourgine et al. $[23,24]$ \\
\hline \multirow[t]{4}{*}{ Combination therapy } & \multirow[t]{2}{*}{ Antivirals and protein vaccine ( $\mathrm{HBsAg}$ ) } & $\mathrm{S}$ & $\begin{array}{l}\text { Dahmen et al. [113] } \\
\text { Horiike et al. [114] } \\
\text { Vandepapeliere et al. [115] }\end{array}$ \\
\hline & & Pre-S1/pre-S2/S & Hoa et al. [28] \\
\hline & \multirow[t]{2}{*}{ Antivirals and $\mathrm{T}$ cell vaccine } & Pre-S2/S & $\begin{array}{l}\text { Godon et al. [26] } \\
\text { Fontaine et al. [25] }\end{array}$ \\
\hline & & Pre-S1/pre-S2/S, HBcAg, polymerase & Yoon et al. [27] \\
\hline
\end{tabular}



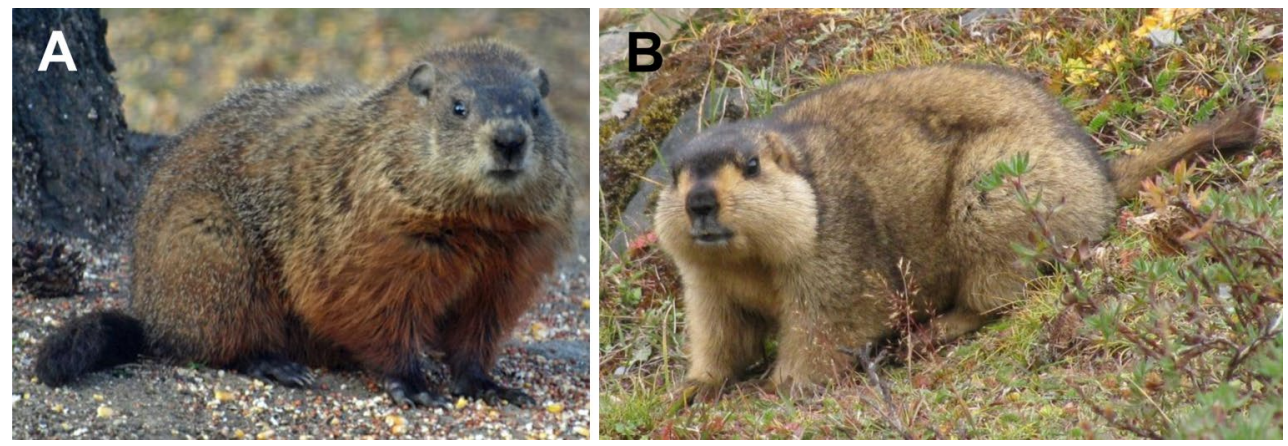

Fig. 1 Pictures of eastern woodchuck M. monax (a) and M. himalayana (b). Himalayan marmots are closely related to the woodchucks and can be infected with WHV. They are about the size of a large housecat and live in colonies

the control over HBV. High load of virus particles and large amounts of HBsAg in the liver and peripheral blood may be responsible for the immune tolerant status in the patients. Therefore, pretreatment with nucleos(t)ide analogues has been proposed to achieve better CD8 $\mathrm{T}$ cell response and subsequent therapeutic efficacy after administration of DNA vaccines.

Recently, the results of the trial of this combination therapy have been published. In a large double-blind study, 70 patients were treated effectively with nucleos(t)ide analogues for a median of 3 years resulting in undetectable levels of HBV DNA and thereafter randomized into two groups: one received five intramuscular injections of DNA vaccine expressing HBsAg and one received placebo. Nucleos $(t)$ ide analogues were stopped. Although this combination therapy was fairly well tolerated, the HBV DNA vaccine did not decrease the risk of relapse in HBV-treated patients and did not restore the anti-HBV immune response despite effective viral suppression by analogues [25, 26].

During a study in Korea, 27 patients randomly received either adefovir (ADV) alone or ADV in combination with HBsAg-expressing DNA vaccine. Therapeutic vaccination was safe and tolerable in CHB patients. Vaccine-induced $\mathrm{HBV}$-specific $\mathrm{T}$ cell responses and $\mathrm{HBeAg}$ seroconversion were weaker in Korean patients than in Caucasian patients [27]. Asian patients, who are generally infected via vertical transmission, may have a higher level of immune tolerance than Caucasians who are usually infected later in life. Improved vaccines for breaking immune tolerance may be needed to develop effective therapeutic HBV DNA vaccines.

The aim of a study in Vietnam was to evaluate viral suppression following combined treatment with a new vaccine containing all three envelope proteins of HBV (pre-S1/pre$\mathrm{S} 2 / \mathrm{S}$ ) and lamivudine in CHB patients. The enhanced suppression of viremia in the combination group was reversed after the discontinuation of vaccine treatment, suggesting that booster doses are required for a sustained viral response. Anti-HBs was detected in 55/120 vaccine recipients, but only three patients demonstrated HBsAg loss, indicating that the vaccine-induced anti-HBs was unable to completely neutralize HBsAg in the serum [28].

\section{Woodchuck model}

The eastern woodchuck (Marmota monax) is naturally infected by woodchuck hepatitis virus (WHV) which was discovered in 1978 [29]. WHV was found to be closely related to hepatitis B virus (HBV) [30] and classified as the second member of the genus ortho-hepadnavirus, family hepadnaviridae. In contrast to $\mathrm{HBV}$-associated $\mathrm{HCC}$ in patients without a preferred integration site of HBV DNA, a frequent integration of the WHV genome close to the $\mathrm{N}$-myc and c-myc gene has been observed in woodchucks developing HCC [31]. Infections of woodchucks with WHV have been shown to be endemic in the Mid-Atlantic States of the USA, whereas in the State of New York and New England woodchucks are rarely infected with WHV. Recently, a Chinese marmot Marmota himalayana was found to be susceptible to WHV infection [32] (Fig. 1). These findings indicate that $M$. himalayana is phylogenetically closely related to M. monax. Therefore, this Chinese Marmota species can be explored as a model for hepadnaviral infection and prevention of infection [33] and in the future for the new therapies.

The molecular characterization of WHV and experimental infection of woodchucks with WHV have been of great value in modelling several aspects of hepadnaviral infection in humans, e.g. the natural course of infection [34-37], immunopathogenesis [38-42], including innate and adaptive immune responses, host and viral factors associated with development of chronicity.

From a medical point of view, the woodchuck model has been used to develop new strategies for prevention of infection [43, 44], post-exposure prophylaxis of hepatitis 
B and therapy of chronic hepadnaviral infection including: nucleoside analogues [45-49], non-nucleoside analogues [50], therapeutic vaccination (reviewed in [51]) and genetherapeutic approaches for treatment of HCC [52]. Liver transplantation has recently been established for woodchucks to study early events in re-infection and adoptive immune transfer [53]. Lately, a significant progress has been made in this model to demonstrate that both cellular immune responses are needed for elimination of the virus from hepatocytes or to at least control viral replication [38, $39,41]$.

This review is focusing on the characterization of woodchuck genes related to innate and adaptive response, the recent development of new tools to determine virusspecific $\mathrm{T}$ cell response, therapeutic vaccines, and finally immunostimulatory and immunomodulatory approaches to treat chronic WHV infection. These new findings in this preclinical model will help the development of new strategies to treat chronic HBV infection in patients.

\section{Cloning and characterization of components of woodchuck immune system}

In recent years, many efforts have been devoted to cloning and characterization of components of the woodchuck immune system. A number of immune function-related genes including cytokines and their receptors, immune cell surface markers and other immune function-related proteins have been cloned and characterized.

So far, important woodchuck cytokines and their receptors such as TNF- $\alpha$, IFN- $\alpha$, IFN- $\gamma$, IL-12, IL-15, GMCSF, lymphotoxin (LT)- $\alpha$ and IL-10R have been cloned and tested for their biological activities [54-61]. In patients, IFN has been used in the treatment of CHB for many years. Therefore, the IFN system has also been characterized in woodchucks. Woodchuck IFN- $\alpha$ was shown to reduce WHV surface antigen expression in a dose-dependent fashion in WHV-infected woodchuck hepatocytes [62]. The woodchuck IFN- $\alpha / \beta$ system and their expression in peripheral blood lymphocytes (PBLs) from naïve and WHV-infected woodchucks have also been studied [63]. The woodchuck IFN- $\alpha$ genes could be classified into ten subtypes and three pseudotypes. Poly(I:C) stimulation on naïve woodchuck PBLs could induce IFN- $\alpha$ subtypes one, four and five production, indicating a selective expression of woodchuck IFN- $\alpha$ subtypes. Moreover, PBLs from chronically WHV-infected woodchucks showed a reduced ability to produce woodchuck IFN when stimulated with poly(I:C). The complete or partial sequences of the type I IFN receptors (IFNARs) of woodchucks were also obtained and analysed by Fan et al. [64]. IFN- $\alpha$ or IFN- $\gamma$ stimulation significantly upregulated IFNAR2 expression in primary woodchuck hepatocytes. A decreased IFNAR1 and IFNAR2 expression was observed in woodchucks chronically infected with WHV. These data are essential for studying type I IFN-related innate immunity and therapy in hepadnaviral infection in the woodchuck model. IL-10 is a pleiotropic cytokine acting on a variety of immune cells through its cell surface receptor (IL-10R). It has been suggested to resuscitate antiviral immunity by interfering with IL-10/IL-10R pathway. An increased production of IL-10 was observed in patients with CHB [65], which hints that blockade of IL-10R might become a feasible therapeutic approach for CHB. Very recently, Jiang et al. [54] successfully cloned woodchuck IL-10R and generated antibodies against this molecule. The blockade of woodchuck IL-10R enhanced the proliferation and degranulation of specific $\mathrm{T}$ cells from chronically WHV-infected woodchucks in vitro. This work provides a basis for potential therapeutic approaches in chronic HBV infection.

Important woodchuck immune cell surface molecules which have been cloned so far can be divided into two categories based on their function: molecules involved in innate immunity and molecules involved in adaptive immunity.

Toll-like receptors (TLRs) are a class of molecules that play a key role in the innate immune system. Recent progress in this field revealed that there are significant interactions between the TLR system and pathogens in chronic viral infections [66]. So far, TLR2, TLR3, TLR4, TLR7, TLR8 and TLR9 have been successfully cloned in woodchucks [67]. In a recent study, Zhang et al. [66] showed that TLR2 ligands induced the activation of NF- $\kappa \mathrm{B}, \mathrm{PI} 3 \mathrm{~K} / \mathrm{Akt}$ and different arms of MAPK signalling pathways and the production of pro-inflammatory cytokines in woodchuck hepatocytes. TLR2-mediated innate immune responses reduced replication and gene expression of $\mathrm{HBV}$ in HepG2.2.15 cells and WHV in primary woodchuck hepatocytes (see also article from Zhang and $\mathrm{Lu}$, in this issue). In chronic WHV carriers woodchuck model, relatively low levels of TLR2 expression were found in PBMCs and in liver tissues. TLR2 expression in PBMCs was inversely correlated with WHV DNA titres in acute WHV infection and in entecavir-treated chronic WHV carriers.

An effective immune response against viral infections depends on the activation of CD8 T cells that can clear infection by killing virus-infected cells. Therefore, sequence information of woodchuck CD3, CD4 and CD8 has been used to determine the kinetic of the influx of $\mathrm{T}$ cells into the liver during incubation period and acute or chronic WHV infection. In week two post-infection, an influx of CD3+ lymphocytes could be observed and reached higher levels prior and during the recovery phase. The peak level of CD4+ and CD8+ $\mathrm{T}$ cells coincided with recovery. During transient infection, $\mathrm{T}$ cells can accumulate in the liver and reach up to two-thirds of the total number of liver cells [35]. In the adaptive immune 
Table 2 Correlation between the outcome of WHV infection and cellular immune response to WHsAg, WHxAg and WHcAg in woodchucks neonatally infected with WHV: 11 woodchucks recovered from infection and 23 developed chronic hepatitis

\begin{tabular}{|c|c|c|c|c|c|c|c|c|}
\hline \multirow[t]{2}{*}{ Outcome of the infection } & \multicolumn{4}{|c|}{$\%$ of woodchucks responding to: } & \multicolumn{4}{|c|}{$\%$ of PBMC samples positive to: } \\
\hline & rWHcAg & rWHsAg & rWHxAg & C97-110 & rWHcAg & rWHsAg & rWHxAg & C97-110 \\
\hline Resolved $(n=11)$ & $100(11 / 11)$ & $82(9 / 11)$ & $91(10 / 11)$ & $100(11 / 11)$ & $59(32 / 54)$ & $34(18 / 53)$ & $34(17 / 50)$ & $51(28 / 55)$ \\
\hline Chronic $(n=23)$ & $39(9 / 23)$ & $22(5 / 23)$ & $26(6 / 23)$ & $17(4 / 23)$ & $6(16 / 262)$ & $2(6 / 242)$ & $4(10 / 242)$ & $2(5 / 265)$ \\
\hline
\end{tabular}

The numbers of PBMC samples detected positive to WHV antigens during the study are given in brackets [41]

response, CD28 and CTLA-4 are known to play important roles for the regulation of $\mathrm{T}$ cell activation by delivering costimulatory signals. The complete coding regions of woodchuck CD28 and cytotoxic T-lymphocyte-associated antigen 4 (CTLA-4) have been cloned and sequenced [68]. Woodchuck CD28 showed a similarity of 76 and $70 \%$ to its human and mouse homologues, respectively, according to the deduced amino acid sequences. Woodchuck CTLA-4 has a higher similarity of 86 and $75 \%$ to the corresponding human and mouse CTLA-4 molecules, respectively. The strict conservation of critical amino acid residues like cysteine and asparagine residues in woodchuck CD28 and CTLA-4 suggests that both molecules may structurally resemble their human or mouse homologues. A hexapeptide motif MYPPPY which has been supposed to be essential for the interaction with CD80 is present in both woodchuck CD28 and CTLA-4 [68].

The advances in sequencing technology provide new tools to characterize genes of the woodchuck immune system in large scale. Fletcher et al. [69] performed the sequencing, assembly and annotation of the woodchuck transcriptome, together with the generation of custom woodchuck microarrays. By using this new platform, they characterized the transcriptional response to persistent WHV infection and WHV-induced HCC. Liu et al. have also performed de novo woodchuck transcriptome assembly by using deep sequencing technology (unpublished data). With the help of this advanced technology, sequence information of important immune genes such as APOBEC3 of woodchucks has been revealed. It has been shown that upregulation of APOBEC3 led to specific and non-hepatotoxic degradation of nuclear HBV cccDNA [70]. Therefore, future cloning and characterizing of APOBEC3 in the woodchuck model will evaluate the therapeutic potential for CHB. In summary, these efforts on establishing the translational value of the woodchuck model can provide new insight into characterizing immune pathways which may play a role in the persistence of HBV infection.

\section{Evaluation of $\mathrm{T}$ cell response in woodchuck model}

Studies in patients underline the important role of $\mathrm{HBV}$ specific $\mathrm{T}$ cell response as a leading factor of viral clearance. For many years, the lack of appropriate methods to evaluate antigen-specific $\mathrm{T}$ cell responses was the serious limitation of this model. The establishment of the assays for monitoring of cellular immune response in woodchucks is of great importance for a reliable evaluation of therapeutic and immunomodulatory strategies for treatment of $\mathrm{CHB}$ in the woodchuck model.

Development of the $2\left[{ }^{3} \mathrm{H}\right]$-adenine-based proliferation assay enabled to detect the T-helper lymphocyte responses after stimulation of woodchuck PBMCs [39, 41]. In addition, several T-helper epitopes within WHcAg [39, 41] were identified in PBMCs from acutely WHV-infected animals. Significant progress in studying the $\mathrm{T}$ cell response of woodchucks was achieved by introduction of the flow cytometric CD107a degranulation assay that enables the detection of WHV-specific cytotoxic T cells (CTLs) in woodchuck PBMCs and splenocytes [38]. Several studies demonstrated that detection of CD107a, as a degranulation marker, is a suitable method for determination of antigenspecific cytotoxic T lymphocytes [71, 72].

Introduction of the immunological tools for studying of the $\mathrm{T}$ cell response in woodchucks revealed a significant similarity between the pathogenesis of WHV infection in woodchucks and HBV in humans. It was demonstrated that acute self-limiting and resolved WHV infections correlate with robust multifunctional T-helper and cytotoxic $\mathrm{T}$ cell responses, while WHV chronic carriers demonstrate weak or no virus-specific $\mathrm{T}$ cell responses against the viral proteins (Table 2) [38, 39, 41]. Moreover, these studies confirmed that the efficient cellular immune response to viral antigens results in liver injury and is necessary for viral clearance.

\section{Therapeutic immunization in the woodchuck model: viral vectors and prime-boost strategy}

Recently described advancements in the characterization and monitoring of the woodchuck immune system during the WHV infection made this animal model particularly useful for development of the immunomodulatory approaches in $\mathrm{CHB}$. The pioneer investigations with therapeutic vaccines based on WHV core [73] or surface 
antigens in combination with a helper peptide named FIS (encompassing amino acids 106-118: FISEAIIHVLHSR from sperm whale myoglobin) [74], or with potent Th1 adjuvants like monophosphoryl lipid A [75] did not lead to satisfactory results. Those experiments proved that vaccinations could induce specific B cell and/or T cell responses in chronic WHV carriers. However, this alone was not sufficient to achieve the control of virus replication, as the very high load of virus may be responsible for the immune tolerant status in the animals. This idea is supported by Boni et al. $[76,77]$ reporting that the $\mathrm{T}$ cell response to $\mathrm{HBV}$ was successfully restored in patients treated with lamivudine. In addition, the quantity of antigen particularly the WHV surface antigen (WHsAg) to which the immune system is exposed can induce different degrees of functional impairment of antiviral $\mathrm{T}$ cells, up to physical $\mathrm{T}$ cell deletion $[78,79]$.

Combination therapy using lamivudine and serumderived WHsAg vaccination showed no effect on induction of anti-WHs antibodies or reduction of WHV DNA [80]. Our group evaluated the efficacy of the combination therapy in the woodchuck model by combining lamivudine treatment, DNA vaccination (three plasmids expressing WHsAg, WHcAg and woodchuck IFN- $\gamma$ ) and WHsAg/ anti-WHs immunogenic complexes vaccination [81]. The triple combination led to a decrease in WHV viral load up to $2.9 \log$, in serum WHsAg up to $92 \%$ and in development of anti-WHs antibodies. Nevertheless, these effects were not sustained and all parameters reached the baseline levels shortly after withdrawal of lamivudine treatment. In addition, the vaccination did not induce WHV-specific $\mathrm{T}$ cell responses in the majority of woodchucks, even in animals that exhibited virological responses. Later, we modified this protocol by using the more potent antiviral drug entecavir (ETV) and increasing the number of the immunizations (with plasmids expressing WHsAg and $\mathrm{WHcAg}$ from three to six) (Lu et al., unpublished results). A significant delay of the rebound of viremia was observed in woodchucks which received additional vaccination, compared to controls treated only with ETV. In another study, chronic WHV carriers received a treatment of the potent antiviral drug clevudine in combination with an alumadsorbed WHsAg vaccine. Combination treatment resulted in significant and sustained reduction of WHV DNA loads and WHsAg concentrations in most treated animals. Compared to vaccination alone, combination treatment induced a more robust anti-WHs response [82, 83].

The results of these studies clearly showed that combination of antiviral treatment and vaccination is more effective in inducing virus-specific $\mathrm{T}$ cell responses than therapeutic vaccination alone. Nevertheless, the efficacy of these approaches was still too limited when applied for treatment of CHB. The vaccination strategies used in some of these studies were even not able to boost a functional antiviral $\mathrm{T}$ cell response. A significantly better induction of $\mathrm{WHcAg}$ specific $\mathrm{T}$ cells using more potent vaccines, such as recombinant viral vectors, may be required to achieve sustained antiviral response and viral clearance.

Recombinant adenoviral vectors (AdV) proved to elicit a vigorous and sustained humoral and $\mathrm{T}$ cell responses to the transduced antigen $[84,85]$. Adenoviral vectors also act as a natural adjuvants causing DC maturation, enhanced antigen presentation and secretion of antiviral cytokines, such as IFN- $\alpha$, TNF- $\alpha$ and IL-6 [86]. However, even single immunization with recombinant adenoviruses may induce immunity, predominantly neutralizing antibodies, against the vector itself. This negative effect of the adenovirusinduced immunity against the vaccine may be overcome by heterologous prime-boost regimen. In particular, subsequent priming immunizations with plasmid DNA vaccine followed by a booster vaccination with AdV seem to be a very promising strategy. DNA prime-adenovirus boost regimen proved to induce more robust and potent immune response in comparison with plasmid DNA alone and provided protection against the pathogen challenge in several animal models of infectious diseases [87-89] (see also article from E. Barnes in this issue).

Recently, our group has investigated whether the heterologous prime-boost immunization strategy using plasmid DNA and recombinant adenoviral vectors may improve the efficacy of the therapeutic vaccination in CHB in the woodchuck model. A new DNA plasmid (pCGWHc) and an adenoviral serotype 5 vector (Ad5WHc) and a chimeric Ad5 displaying Ad35 fibre (Ad35WHc) showing high expression levels of WHcAg were constructed [90]. The increased antigen expression was achieved by insertion of an intron sequence in the expression cassette of the vaccines. Preliminary results showed that the new vaccines are able to induce strong and sustained $\mathrm{WHcAg}$-specific $\mathrm{T}$ cell response in mice and naïve woodchucks. Interestingly, immunization with AdVs led to rapid and massive production of anti-WHs antibodies and as a result resolution of infection after the WHV challenge [90].

The DNA prime-AdV boost immunization strategy was further used as a therapeutic vaccine against chronic WHV infection in combination with antiviral treatment with ETV. Six chronically WHV-infected woodchucks were treated for 23 weeks with ETV. Starting from week eight, four of the six ETV-treated animals received subsequently nine intramuscular immunizations with: DNA plasmids expressing WHcAg (pCGWHc) and WHsAg (pWHsIm), Ad5WHc and Ad35WHc. WHsAg- and WHcAg-specific T-helper and cytotoxic $\mathrm{T}$ cell responses were detected in all chronic carriers that received immunizations, but not in ETV only treated animals. In addition, woodchucks receiving the combination therapy showed a prolonged suppression 
of WHV replication and lower WHsAg levels compared to controls. Excitingly, two of four immunized carriers remained WHV DNA negative after the end of ETV treatment and developed anti-WHs antibodies [91]. These data are encouraging and demonstrate that the combined antiviral and vaccination approach efficiently elicited sustained immunological control of chronic hepadnaviral infection in woodchucks.

\section{Combining therapeutic vaccination and modulation of $\mathbf{T}$ cell function}

Persistent HBV infection is associated with functional exhaustion of virus-specific CD8 T cells [92]. This defect in virus-specific $\mathrm{T}$ cells is one of the primary reasons for the inability of the host to eliminate the persisting pathogen. Although it has been shown that nucleoside analogues treatment can induce the recovery of HBV-specific CTL activity in patients [76], this effect is only transient [77]. Those findings are consistent with our data obtained from the woodchuck model, in which ETV treatment alone only induced either only transient CTL responses [91] or no responses at all [93]. Therefore, additional strategies that can potently enhance $\mathrm{T}$ cell response need to be enroled for the treatment of CHB infection.

Recent studies in chronic virus infection models indicate that the interaction between the inhibitory receptor programmed death-1 (PD-1) and its ligands plays a critical role in $\mathrm{T}$ cell exhaustion [94-97]. In chronic HBV infections, upregulation of PD-1 on virus-specific T cells was observed, and restoration of the $\mathrm{T}$ cell function has been achieved by blocking the PD-1/PD-ligand 1 (PD-L1) interaction in vitro [98]. Recently, the therapeutic effect of PD-1/PD-L1 blockade has also been investigated for chronic HCV infection in chimpanzees [99] and in patients [100]. However, limited effect on restoring $\mathrm{T}$ cell function was observed in these studies which used only PD-1/PD-L1 blockade. It has been recently clarified that the proportion of CD8 T cells expressing PD-1 and the levels of PD-1 on virus-specific T cells are strongly correlated with viral load in the plasma [101-103]. Antiretroviral treatment resulted in the dramatic decline of plasma viral load, coincident with a decrease in the PD-1 expression level on virus-specific CD8 T cells [101, 103]. In line with this, a better restoration of $\mathrm{T}$ cell functions upon in vitro anti-PD-L1 treatment was observed in chronic HBV patients with lower viremia [104]. Therefore, a combination therapy that includes direct antiviral drug and PD-L1 blockade is a reasonable strategy for the treatment of chronic HBV infection.

In line with these findings, Zhang et al. [105] and Liu et al. [93] successfully cloned and characterized the woodchuck PD-1/PD-L system in the WHV infection woodchuck model. A significant positive correlation between the viral load and the PD-1 expression on total CD8 T cells in chronic WHV infection was observed. Both the proportion of PD-1+ CD8 T cells and the levels of PD-1 expression on CD8 $\mathrm{T}$ cells were significantly higher in the woodchucks with chronic WHV infection compared to naïve animals and resolvers. More importantly, during ETV treatment of those chronic carriers, a reduction of serum viral load was correlated with a dramatic decrease in the level of PD-1 expression on CD8 T cells [93]. In vitro blockade of woodchuck PD-1/PD-L1 pathway by using a rabbit polyclonal PD-L1 blocking antibody could partially restore the T cell function in WHV-infected woodchucks [105]. Moreover, in vivo blockade of the PD-1/PD-L1 pathway on CD8 T cells, in combination with nucleoside analogue treatment and DNA vaccination, synergistically enhanced the function of virus-specific $\mathrm{T}$ cells. The combination therapy potently suppressed WHV replication, leading to sustained immunological control of viral infection, anti-WHs antibody development and complete viral clearance in some woodchucks [93]. Although similar approaches have been tried in other viruses in the past, such as LCMV, the data presented here may be an advance for the HBV field to new approaches for eliminating the virus itself rather than only suppressing its replication.

\section{Summary and conclusion}

The woodchuck is a valuable preclinical model for developing new therapeutic approaches in chronic hepadnaviral infections. Even though several innovative approaches combining antiviral treatment with nucleoside analogues, DNA vaccines and protein vaccines were tested in chronically infected woodchucks, the effectiveness of those strategies was very limited. Strategies investigated so far were often hampered by weak $\mathrm{T}$ cell responses observed after immunization, suggesting a strong need for alternative strategies to enhance $\mathrm{T}$ cell functions during chronic HBV infection. Recently, our group published two independent proof-of-concept studies, showing that using a very potent $\mathrm{T}$ cell vaccine and blockade of negative signalling in $\mathrm{T}$ cells may lead to the resolution of chronic hepatitis B in some woodchucks (Table 3). These data are encouraging and implicate the feasibility and usefulness of the immunotherapeutic strategies for the treatment of chronically HBV-infected patients. Nevertheless, which factors influence the effect of therapeutic vaccination remains to be further investigated. It has been noticed that satisfactory therapeutic effects could not be documented in the studies using HBsAgbased prophylactic vaccines. In the mean time, evidence has supported that $\mathrm{HBcAg}$-specific immunity is endowed with antiviral and liver-protecting capacities in $\mathrm{CHB}$ patients and animal models. With the increasing number of available 
Table 3 Summary of four preclinical studies of combination therapy with entecavir and $\mathrm{T}$ cell vaccine performed in woodchucks

\begin{tabular}{|c|c|c|c|c|c|c|c|}
\hline \multirow{2}{*}{$\begin{array}{l}\text { Study no. } \\
\text { [reference] }\end{array}$} & \multirow{2}{*}{$\begin{array}{l}\text { Number of } \\
\text { treated animals }\end{array}$} & \multirow{2}{*}{$\begin{array}{l}\text { Antiviral } \\
\text { treatment }\end{array}$} & \multirow{2}{*}{$\begin{array}{l}\text { Duration } \\
\text { months }\end{array}$} & \multirow[t]{2}{*}{ Vaccines } & \multirow{2}{*}{$\begin{array}{l}\text { Number of } \\
\text { shots }\end{array}$} & \multicolumn{2}{|l|}{ Outcome } \\
\hline & & & & & & $\begin{array}{l}\text { Delayed } \\
\text { rebound }\end{array}$ & $\begin{array}{l}\text { WHV DNA neg. } \\
\text { in follow-up }\end{array}$ \\
\hline $\begin{array}{l}\text { 1. Lu et al. } \\
\text { (unpublished) }\end{array}$ & 9 & ETV $0.5 \mathrm{mg} / \mathrm{kg}$ & 6 & $\begin{array}{l}\text { DNA vaccine } \\
\text { WHsAg, } \\
\text { WHcAg }\end{array}$ & 6 & $9 / 9$ & $1 / 7(14.3 \%)$ \\
\hline $\begin{array}{l}\text { 2. Lu et al. } \\
\text { (unpublished) }\end{array}$ & 6 & ETV $0.2 \mathrm{mg}$ & 12 & $\begin{array}{l}\text { DNA vaccine } \\
\text { WHsAg, } \\
\text { WHcAg }\end{array}$ & 12 & $6 / 6$ & $2 / 6(33.3 \%)$ \\
\hline 3. [91] & 4 & ETV $0.2 \mathrm{mg} / \mathrm{kg}$ & 6 & $\begin{array}{l}\text { DNA and } \\
\text { AdV vaccine } \\
\text { WHcAg }\end{array}$ & 9 & $4 / 4$ & $2 / 4(50.0 \%)$ \\
\hline 4. [93] & 3 & ETV $0.2 \mathrm{mg} / \mathrm{kg}$ & 6 & $\begin{array}{l}\text { DNA vaccine } \\
\text { WHsAg, } \\
\text { WHcAg } \\
\text { Anti-PDL1 }\end{array}$ & 12 & $3 / 3$ & $2 / 3(66.7 \%)$ \\
\hline Total & $\begin{array}{l}22 \text { vaccinated ar } \\
\text { Ten control anin }\end{array}$ & $\begin{array}{l}\text { mals } \\
\text { als in four studies }\end{array}$ & & & & $\begin{array}{l}22 / 22 \\
0 / 10\end{array}$ & $\begin{array}{l}7 / 20(35.0 \%) \\
0 / 10\end{array}$ \\
\hline
\end{tabular}

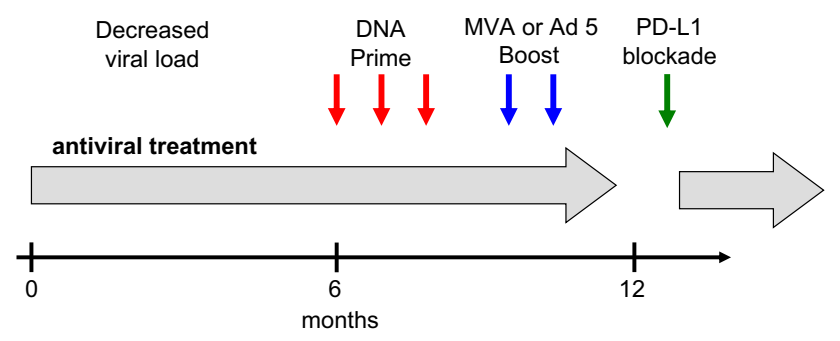

Fig. 2 Potential schemes for immunotherapy of patients with chronic hepatitis B. Ideally, patients should be already HBV DNA negative under antiviral treatment, have seroconverted to anti-HBe, have low or moderate $\mathrm{HBsAg}$ concentrations and normal or only slightly elevated ALT at beginning of vaccination or/and PDL-1 antibody treatment. Three options for combination with nucleot(s)ide analogues therapy are suggested: (1) PDL-1 blockade; (2) prime-boost vaccination; (3) prime-boost vaccination and subsequent PDL-1 blockade

vaccine formulation, a more crucial question raised recently: what is the optimal combination of these vaccines. Obviously, it is necessary to test the mutual influences of different types of vaccines to maximize their effects and avoid the negative interference between the vaccines. Also, the question how HBV infection leads to defective immune responses to HBV proteins remains to be investigated. This issue is the key to a more rational design of new therapeutic approaches. Figure 2 summarizes the ideas of a potential combination treatment for patients with chronic hepatitis B.

\section{Unresolved problems}

The presence of viral components may be a main reason for $\mathrm{T}$ cell tolerance in chronic $\mathrm{HBV}$ infection. Antiviral treatment with nucleoside analogues efficiently reduce HBV replication and release of new virions and may partly restore $\mathrm{HBV}$-specific $\mathrm{CD} 8$ and $\mathrm{CD} 4 \mathrm{~T}$ cell responses, thereby allowing successful therapeutic vaccination. However, HBV proteins are still produced as the transcription of mRNAs for the $S$ protein and the core protein on HBV cccDNA is not affected by antiviral treatment. Even when HBV DNA disappears during antiviral treatment, $\mathrm{HBsAg}$ and $\mathrm{HBcAg} / \mathrm{HBeAg}$ are present in the liver or in blood at high levels. It is proposed to reduce HBV protein load by small interfering RNAs (siRNAs), which lead to the sequence-specific degradation of homologous mRNA. Using this RNA interference (RNAi) with chemically synthesized or vector-expressed siRNAs, many clinically relevant viruses including the human immunodeficiency virus, HBV and HCV could be inhibited. In in vitro experiments showed that WHV transcripts could be degraded by siRNAs [106]. At the same time, the degradation of viral RNAs resulted in the activation of multiple pathways of host innate immune responses [107]. However, future in vivo studies are required to demonstrate the usefulness of this technology. Combining gene-silencing approach with nucleoside analogues may further facilitate the stimulation of the immune system by therapeutic vaccines.

The epigenetic regulation provides an alternative to interfere with HBV gene expression. HBV minichromosome in hepatocytes is under the complex control of epigenetic mechanisms, and its transcriptional activity could be influenced by methylation, histone acetylation and other mechanisms [108]. Therefore, exploring epigenetic drugs to modify, these regulatory processes may achieve an effective suppression of HBV gene expression and thereby replace antiviral treatment with nucleoside analogues. 
The stimulation of innate immune responses may contribute to the control of HBV infection. In this special issue, Zhang and Lu provided a review dedicating to the role of TLR system. Interferons and interferon-stimulated genes (ISGs) represent still an important part for anti-HBV treatment. A recent review about this aspect described the current progress (Pei et al., in press). Recently, the antiviral functions of ISGs are under studies. For example, interferon-induced protein with tetratricopeptide repeats 1 and 2 is a cellular factor that was shown to limit hepatitis $B$ virus replication in hepatoma cells [109]. Another recent report by Lucifora et al. [70] about the role of APOBECs in the degradation of cccDNA was highly interesting, but remained to be controversial [110, 111]. Future investigation is required to elucidate the functions of ISGs and their relative contribution for control of $\mathrm{HBV}$ infection, before exploring these genes for antiviral treatment.

Acknowledgments The authors thank Dr. Wolfram Gerlich for his critical comments on this manuscript. A number of studies cited in this review were funded by Deutsche Forschungsgemeinschaft (GK 1045 and SFB/TRR60).

\section{Conflict of interest None.}

Open Access This article is distributed under the terms of the Creative Commons Attribution License which permits any use, distribution, and reproduction in any medium, provided the original author(s) and the source are credited.

\section{References}

1. Ott JJ, Stevens GA, Groeger J, Wiersma ST (2012) Global epidemiology of hepatitis B virus infection: new estimates of age-specific HBsAg seroprevalence and endemicity. Vaccine 30:2212-2219

2. Janssen HL, van Zonneveld M, Senturk H, Zeuzem S, Akarca US et al (2005) Pegylated interferon alfa-2b alone or in combination with lamivudine for $\mathrm{HBeAg}$-positive chronic hepatitis B: a randomised trial. Lancet 365:123-129

3. Lau GK, Piratvisuth T, Luo KX, Marcellin P, Thongsawat S et al (2005) Peginterferon Alfa-2a, lamivudine, and the combination for HBeAg-positive chronic hepatitis B. N Engl J Med 352:2682-2695

4. Locarnini S, Mason WS (2006) Cellular and virological mechanisms of HBV drug resistance. J Hepatol 44:422-431

5. Zoulim F, Locarnini S (2009) Hepatitis B virus resistance to nucleos(t)ide analogues. Gastroenterology 137(1593-1608): e1591-e1592

6. Penna A, Artini M, Cavalli A, Levrero M, Bertoletti A et al (1996) Long-lasting memory $\mathrm{T}$ cell responses following selflimited acute hepatitis B. J Clin Invest 98:1185-1194

7. Rehermann B, Ferrari C, Pasquinelli C, Chisari FV (1996) The hepatitis B virus persists for decades after patients' recovery from acute viral hepatitis despite active maintenance of a cytotoxic T-lymphocyte response. Nat Med 2:1104-1108

8. Rehermann B, Lau D, Hoofnagle JH, Chisari FV (1996) Cytotoxic $\mathrm{T}$ lymphocyte responsiveness after resolution of chronic hepatitis B virus infection. J Clin Invest 97:1655-1665

9. Couillin I, Pol S, Mancini M, Driss F, Brechot C et al (1999) Specific vaccine therapy in chronic hepatitis B: induction of
$\mathrm{T}$ cell proliferative responses specific for envelope antigens. $\mathrm{J}$ Infect Dis 180:15-26

10. Dikici B, Bosnak M, Ucmak H, Dagli A, Ece A et al (2003) Failure of therapeutic vaccination using hepatitis B surface antigen vaccine in the immunotolerant phase of children with chronic hepatitis B infection. J Gastroenterol Hepatol $18: 218-222$

11. Dikici B, Kalayci AG, Ozgenc F, Bosnak M, Davutoglu M et al (2003) Therapeutic vaccination in the immunotolerant phase of children with chronic hepatitis B infection. Pediatr Infect Dis J 22:345-349

12. Jung MC, Gruner N, Zachoval R, Schraut W, Gerlach $\mathrm{T}$ et al (2002) Immunological monitoring during therapeutic vaccination as a prerequisite for the design of new effective therapies: induction of a vaccine-specific CD4+ T-cell proliferative response in chronic hepatitis B carriers. Vaccine 20:3598-3612

13. Pol S, Driss F, Michel ML, Nalpas B, Berthelot P et al (1994) Specific vaccine therapy in chronic hepatitis B infection. Lancet 344:342

14. Pol S, Nalpas B, Driss F, Michel ML, Tiollais P et al (2001) Efficacy and limitations of a specific immunotherapy in chronic hepatitis B. J Hepatol 34:917-921

15. Ren F, Hino K, Yamaguchi Y, Funatsuki K, Hayashi A et al (2003) Cytokine-dependent anti-viral role of CD4-positive T cells in therapeutic vaccination against chronic hepatitis B viral infection. J Med Virol 71:376-384

16. Safadi R, Israeli E, Papo O, Shibolet O, Melhem A et al (2003) Treatment of chronic hepatitis $\mathrm{B}$ virus infection via oral immune regulation toward hepatitis B virus proteins. Am J Gastroenterol 98:2505-2515

17. Yalcin K, Acar M, Degertekin H (2003) Specific hepatitis B vaccine therapy in inactive HBsAg carriers: a randomized controlled trial. Infection 31:221-225

18. Wen YM, Wu XH, Hu DC, Zhang QP, Guo SQ (1995) Hepatitis $\mathrm{B}$ vaccine and anti-HBs complex as approach for vaccine therapy. Lancet 345:1575-1576

19. Yao X, Zheng B, Zhou J, Xu DZ, Zhao K et al (2007) Therapeutic effect of hepatitis B surface antigen-antibody complex is associated with cytolytic and non-cytolytic immune responses in hepatitis B patients. Vaccine 25:1771-1779

20. Wang XY, Zhang XX, Yao X, Jiang JH, Xie YH et al (2010) Serum $\mathrm{HBeAg}$ sero-conversion correlated with decrease of HBsAg and HBV DNA in chronic hepatitis B patients treated with a therapeutic vaccine. Vaccine 28:8169-8174

21. Xu DZ, Zhao K, Guo LM, Li LJ, Xie Q et al (2008) A randomized controlled phase IIb trial of antigen-antibody immunogenic complex therapeutic vaccine in chronic hepatitis B patients. PLoS ONE 3:e2565

22. Xu DZ, Wang XY, Shen XL, Gong GZ, Ren H et al (2013) Results of a phase III clinical trial with an HBsAg-HBIG immunogenic complex therapeutic vaccine for chronic hepatitis B patients: experiences and findings. J Hepatol 59:450-456

23. Mancini-Bourgine M, Fontaine H, Brechot C, Pol S, Michel ML (2006) Immunogenicity of a hepatitis B DNA vaccine administered to chronic HBV carriers. Vaccine 24:4482-4489

24. Mancini-Bourgine M, Fontaine H, Scott-Algara D, Pol S, Brechot $C$ et al (2004) Induction or expansion of T-cell responses by a hepatitis B DNA vaccine administered to chronic HBV carriers. Hepatology 40:874-882

25. Fontaine H, Kahi S, Chazallon C, Bourgine M, Varaut A et al (2014) Anti-HBV DNA vaccination does not prevent relapse after discontinuation of analogues in the treatment of chronic hepatitis B: a randomised trial-ANRS HB02 VAC-ADN. Gut. doi:10.1136/gutjnl-2013-305707

26. Godon O, Fontaine H, Kahi S, Meritet J, Scott-Algara D et al (2014) Immunological and antiviral responses after therapeutic 
DNA immunization in chronic hepatitis B patients efficiently treated by analogues. Mol Ther 22:675-684

27. Yoon SK, Seo YB, Im SJ, Bae SH, Song MJ et al (2014) Safety and immunogenicity of therapeutic DNA vaccine with antiviral drug in chronic HBV patients and its immunogenicity in mice. Liver Int. doi:10.1111/liv.12530

28. Hoa PT, Huy NT, le Thu T, Nga CN, Nakao K et al (2009) Randomized controlled study investigating viral suppression and serological response following pre-S1/pre-S2/S vaccine therapy combined with lamivudine treatment in $\mathrm{HBeAg}$-positive patients with chronic hepatitis B. Antimicrob Agents Chemother 53:5134-5140

29. Summers J, Smolec JM, Snyder R (1978) A virus similar to human hepatitis B virus associated with hepatitis and hepatoma in woodchucks. Proc Natl Acad Sci USA 75:4533-4537

30. Galibert F, Chen TN, Mandart E (1981) Localization and nucleotide sequence of the gene coding for the woodchuck hepatitis virus surface antigen: comparison with the gene coding for the human hepatitis B virus surface antigen. Proc Natl Acad Sci USA 78:5315-5319

31. Moroy T, Marchio A, Etiemble J, Trepo C, Tiollais P et al (1986) Rearrangement and enhanced expression of c-myc in hepatocellular carcinoma of hepatitis virus infected woodchucks. Nature 324:276-279

32. Wang BJ, Tian YJ, Meng ZJ, Jiang M, Wei BQ et al (2011) Establishing a new animal model for hepadnaviral infection: susceptibility of Chinese Marmota-species to woodchuck hepatitis virus infection. J Gen Virol 92:681-691

33. Wang B, Zhu Z, Zhu B, Wang J, Song Z et al (2014) Nucleoside analogues alone or combined with vaccination prevent hepadnavirus viremia and induce protective immunity: alternative strategy for hepatitis B virus post-exposure prophylaxis. Antiviral Res 105:118-125

34. Cote PJ, Toshkov I, Bellezza C, Ascenzi M, Roneker C et al (2000) Temporal pathogenesis of experimental neonatal woodchuck hepatitis virus infection: increased initial viral load and decreased severity of acute hepatitis during the development of chronic viral infection. Hepatology 32:807-817

35. Guo JT, Zhou H, Liu C, Aldrich C, Saputelli J et al (2000) Apoptosis and regeneration of hepatocytes during recovery from transient hepadnavirus infections. J Virol 74:1495-1505

36. Kajino K, Jilbert AR, Saputelli J, Aldrich CE, Cullen J et al (1994) Woodchuck hepatitis virus infections: very rapid recovery after a prolonged viremia and infection of virtually every hepatocyte. J Virol 68:5792-5803

37. Yamamoto T, Litwin S, Zhou T, Zhu Y, Condreay L et al (2002) Mutations of the woodchuck hepatitis virus polymerase gene that confer resistance to lamivudine and 2'-fluoro-5-methyl-beta-L-arabinofuranosyluracil. J Virol 76:1213-1223

38. Frank I, Budde C, Fiedler M, Dahmen U, Viazov S et al (2007) Acute resolving woodchuck hepatitis virus (WHV) infection is associated with a strong cytotoxic T-lymphocyte response to a single WHV core peptide. J Virol 81:7156-7163

39. Menne S, Maschke J, Lu M, Grosse-Wilde H, Roggendorf M (1998) T-Cell response to woodchuck hepatitis virus (WHV) antigens during acute self-limited WHV infection and convalescence and after viral challenge. J Virol 72:6083-6091

40. Menne S, Maschke J, Tolle T, Kreuzfelder E, Grosse-Wilde H et al (1997) Determination of peripheral blood mononuclear cell responses to mitogens and woodchuck hepatitis virus core antigen in woodchucks by 5 -bromo-2'-deoxyuridine or $2[3 \mathrm{H}]$ adenine incorporation. Arch Virol 142:511-521

41. Menne S, Roneker CA, Roggendorf M, Gerin JL, Cote PJ et al (2002) Deficiencies in the acute-phase cell-mediated immune response to viral antigens are associated with development of chronic woodchuck hepatitis virus infection following neonatal inoculation. J Virol 76:1769-1780

42. Nakamura I, Nupp JT, Cowlen M, Hall WC, Tennant BC et al (2001) Pathogenesis of experimental neonatal woodchuck hepatitis virus infection: chronicity as an outcome of infection is associated with a diminished acute hepatitis that is temporally deficient for the expression of interferon gamma and tumor necrosis factor-alpha messenger RNAs. Hepatology 33:439-447

43. Garcia-Navarro R, Blanco-Urgoiti B, Berraondo P, Sanchez de la Rosa R, Vales A et al (2001) Protection against woodchuck hepatitis virus (WHV) infection by gene gun coimmunization with WHV core and interleukin-12. J Virol 75:9068-9076

44. Lu M, Hilken G, Kruppenbacher J, Kemper T, Schirmbeck $\mathrm{R}$ et al (1999) Immunization of woodchucks with plasmids expressing woodchuck hepatitis virus (WHV) core antigen and surface antigen suppresses WHV infection. J Virol 73:281-289

45. Cullen JM, Smith SL, Davis MG, Dunn SE, Botteron C et al (1997) In vivo antiviral activity and pharmacokinetics of (-)-cis5-fluoro-1-[2-(hydroxymethyl)-1,3-oxathiolan-5-yl]cytosine in woodchuck hepatitis virus-infected woodchucks. Antimicrob Agents Chemother 41:2076-2082

46. Genovesi EV, Lamb L, Medina I, Taylor D, Seifer M et al (2000) Antiviral efficacy of lobucavir (BMS-180194), a cyclobutyl-guanosine nucleoside analogue, in the woodchuck (Marmota monax) model of chronic hepatitis B virus (HBV) infection. Antiviral Res 48:197-203

47. Korba BE, Schinazi RF, Cote P, Tennant BC, Gerin JL (2000) Effect of oral administration of emtricitabine on woodchuck hepatitis virus replication in chronically infected woodchucks. Antimicrob Agents Chemother 44:1757-1760

48. Mason WS, Cullen J, Moraleda G, Saputelli J, Aldrich CE et al (1998) Lamivudine therapy of WHV-infected woodchucks. Virology 245:18-32

49. Peek SF, Cote PJ, Jacob JR, Toshkov IA, Hornbuckle WE et al (2001) Antiviral activity of clevudine [L-FMAU, (1-(2-fluoro5-methyl-beta, L-arabinofuranosyl) uracil)] against woodchuck hepatitis virus replication and gene expression in chronically infected woodchucks (Marmota monax). Hepatology 33:254-266

50. Block TM, Lu X, Mehta AS, Blumberg BS, Tennant B et al (1998) Treatment of chronic hepadnavirus infection in a woodchuck animal model with an inhibitor of protein folding and trafficking. Nat Med 4:610-614

51. Kosinska AD, Zhang E, Lu M, Roggendorf M (2010) Therapeutic vaccination in chronic hepatitis B: preclinical studies in the woodchuck. Hepat Res Treat 2010:817580

52. Putzer BM, Stiewe T, Rodicker F, Schildgen O, Ruhm S et al (2001) Large nontransplanted hepatocellular carcinoma in woodchucks: treatment with adenovirus-mediated delivery of interleukin 12/B7.1 genes. J Natl Cancer Inst 93:472-479

53. Dahmen U, Dirsch O, Li J, Fiedle M, Lu M et al (2004) Adoptive transfer of immunity: a new strategy to interfere with severe hepatitis virus reinfection after woodchuck liver transplantation. Transplantation 77:965-972

54. Jiang M, Liu J, Zhang E, Meng Z, Wang B et al (2012) Molecular characterization of woodchuck interleukin-10 receptor and enhanced function of specific $\mathrm{T}$ cells from chronically infected woodchucks following its blockade. Comp Immunol Microbiol Infect Dis 35:563-573

55. Li DH, Havell EA, Brown CL, Cullen JM (2000) Woodchuck lymphotoxin-alpha, -beta and tumor necrosis factor genes: structure, characterization and biological activity. Gene 242:295-305

56. Liu CJ, Huang YJ, Chen HL, Lin HT, Lin HL et al (2009) Characterization of interleukin 8 in woodchucks with chronic hepatitis B and hepatocellular carcinoma. Genes Immun 10:27-36 
57. Lohrengel B, Lu M, Bauer D, Roggendorf M (2000) Expression and purification of woodchuck tumour necrosis factor alpha. Cytokine 12:573-577

58. Lohrengel B, Lu M, Roggendorf M (1998) Molecular cloning of the woodchuck cytokines: TNF-alpha, IFN-gamma, and IL-6. Immunogenetics 47:332-335

59. Lu M, Lohrengel B, Hilken G, Kemper T, Roggendorf M (2002) Woodchuck gamma interferon upregulates major histocompatibility complex class I transcription but is unable to deplete woodchuck hepatitis virus replication intermediates and RNAs in persistently infected woodchuck primary hepatocytes. J Virol 76:58-67

60. Wang B, Lohrengel B, Lu Y, Meng Z, Xu Y et al (2005) Molecular characterization of woodchuck interleukin 15 (wIL-15) and detection of its expression in liver samples of woodchucks infected with woodchuck hepatitis virus (WHV). Cytokine 32:296-303

61. Wu HL, Chen PJ, Lin HK, Lee RS, Lin HL et al (2001) Molecular cloning and expression of woodchuck granulocyte-macrophage colony stimulating factor. J Med Virol 65:567-575

62. Salucci V, Lu M, Aurisicchio L, La Monica N, Roggendorf M et al (2002) Expression of a new woodchuck IFN-alpha gene by a helper-dependent adenoviral vector in woodchuck hepatitis virus-infected primary hepatocytes. J Interferon Cytokine Res 22:1027-1034

63. Lu Y, Xu Y, Yang D, Kemper T, Roggendorf M et al (2008) Molecular characterization of woodchuck type I interferons and their expression by woodchuck peripheral blood lymphocytes. Cytokine 41:127-135

64. Fan H, Zhu Z, Wang Y, Zhang X, Lu Y et al (2012) Molecular characterization of the type I IFN receptor in two woodchuck species and detection of its expression in liver samples from woodchucks infected with woodchuck hepatitis virus (WHV). Cytokine 60:179-185

65. Rico MA, Quiroga JA, Subira D, Castanon S, Esteban JM et al (2001) Hepatitis B virus-specific T-cell proliferation and cytokine secretion in chronic hepatitis B e antibody-positive patients treated with ribavirin and interferon alpha. Hepatology 33:295-300

66. Zhang X, Ma Z, Liu H, Liu J, Meng Z et al (2012) Role of Tolllike receptor 2 in the immune response against hepadnaviral infection. J Hepatol 57:522-528

67. Zhang X, Meng Z, Qiu S, Xu Y, Yang D et al (2009) Lipopolysaccharide-induced innate immune responses in primary hepatocytes downregulates woodchuck hepatitis virus replication via interferon-independent pathways. Cell Microbiol 11:1624-1637

68. Yang D, Roggendorf M, Lu M (2003) Molecular characterization of CD28 and cytotoxic T-lymphocyte-associated antigen 4 (CTLA-4) of woodchuck (Marmota monax). Tissue Antigens 62:225-232

69. Fletcher SP, Chin DJ, Ji Y, Iniguez AL, Taillon B et al (2012) Transcriptomic analysis of the woodchuck model of chronic hepatitis B. Hepatology 56:820-830

70. Lucifora J, Xia Y, Reisinger F, Zhang K, Stadler D et al (2014) Specific and nonhepatotoxic degradation of nuclear hepatitis $\mathrm{B}$ virus cccDNA. Science 343:1221-1228

71. Betts MR, Brenchley JM, Price DA, De Rosa SC, Douek DC et al (2003) Sensitive and viable identification of antigen-specific CD8+ $\mathrm{T}$ cells by a flow cytometric assay for degranulation. J Immunol Methods 281:65-78

72. Rubio V, Stuge TB, Singh N, Betts MR, Weber JS et al (2003) Ex vivo identification, isolation and analysis of tumor-cytolytic T cells. Nat Med 9:1377-1382

73. Roggendorf M, Tolle TK (1995) The woodchuck: an animal model for hepatitis B virus infection in man. Intervirology $38: 100-112$
74. Hervas-Stubbs S, Lasarte JJ, Sarobe P, Prieto J, Cullen J et al (1997) Therapeutic vaccination of woodchucks against chronic woodchuck hepatitis virus infection. J Hepatol 27:726-737

75. Lu M, Klaes R, Menne S, Gerlich W, Stahl B et al (2003) Induction of antibodies to the PreS region of surface antigens of woodchuck hepatitis virus (WHV) in chronic carrier woodchucks by immunizations with WHV surface antigens. J Hepatol 39:405-413

76. Boni C, Penna A, Ogg GS, Bertoletti A, Pilli M et al (2001) Lamivudine treatment can overcome cytotoxic T-cell hyporesponsiveness in chronic hepatitis B: new perspectives for immune therapy. Hepatology 33:963-971

77. Boni C, Penna A, Bertoletti A, Lamonaca V, Rapti I et al (2003) Transient restoration of anti-viral $\mathrm{T}$ cell responses induced by lamivudine therapy in chronic hepatitis B. J Hepatol 39:595-605

78. Wherry EJ, Ha SJ, Kaech SM, Haining WN, Sarkar S et al (2007) Molecular signature of CD8 + T cell exhaustion during chronic viral infection. Immunity 27:670-684

79. Freeman GJ, Wherry EJ, Ahmed R, Sharpe AH (2006) Reinvigorating exhausted HIV-specific T cells via PD-1-PD-1 ligand blockade. J Exp Med 203:2223-2227

80. Hervas-Stubbs S, Lasarte JJ, Sarobe P, Vivas I, Condreay L et al (2001) T-helper cell response to woodchuck hepatitis virus antigens after therapeutic vaccination of chronically-infected animals treated with lamivudine. J Hepatol 35:105-111

81. Lu M, Yao X, Xu Y, Lorenz H, Dahmen U et al (2008) Combination of an antiviral drug and immunomodulation against hepadnaviral infection in the woodchuck model. J Virol 82:2598-2603

82. Menne S, Roneker CA, Korba BE, Gerin JL, Tennant BC et al (2002) Immunization with surface antigen vaccine alone and after treatment with 1-(2-fluoro-5-methyl-beta-Larabinofuranosyl)-uracil (L-FMAU) breaks humoral and cellmediated immune tolerance in chronic woodchuck hepatitis virus infection. J Virol 76:5305-5314

83. Menne S, Roneker CA, Tennant BC, Korba BE, Gerin JL et al (2002) Immunogenic effects of woodchuck hepatitis virus surface antigen vaccine in combination with antiviral therapy: breaking of humoral and cellular immune tolerance in chronic woodchuck hepatitis virus infection. Intervirology 45:237-250

84. Shiver JW, Fu TM, Chen L, Casimiro DR, Davies ME et al (2002) Replication-incompetent adenoviral vaccine vector elicits effective anti-immunodeficiency-virus immunity. Nature 415:331-335

85. Zakhartchouk AN, Liu Q, Petric M, Babiuk LA (2005) Augmentation of immune responses to SARS coronavirus by a combination of DNA and whole killed virus vaccines. Vaccine 23:4385-4391

86. Morelli AE, Larregina AT, Ganster RW, Zahorchak AF, Plowey $\mathrm{JM}$ et al (2000) Recombinant adenovirus induces maturation of dendritic cells via an NF-kappaB-dependent pathway. J Virol 74:9617-9628

87. Sullivan NJ, Sanchez A, Rollin PE, Yang ZY, Nabel GJ (2000) Development of a preventive vaccine for Ebola virus infection in primates. Nature 408:605-609

88. Casimiro DR, Wang F, Schleif WA, Liang X, Zhang ZQ et al (2005) Attenuation of simian immunodeficiency virus SIVmac239 infection by prophylactic immunization with dna and recombinant adenoviral vaccine vectors expressing Gag. J Virol 79:15547-15555

89. Xin KQ, Jounai N, Someya K, Honma K, Mizuguchi H et al (2005) Prime-boost vaccination with plasmid DNA and a chimeric adenovirus type 5 vector with type 35 fiber induces protective immunity against HIV. Gene Ther 12:1769-1777

90. Kosinska AD, Johrden L, Zhang E, Fiedler M, Mayer A et al (2012) DNA prime-adenovirus boost immunization induces 
a vigorous and multifunctional T-cell response against hepadnaviral proteins in the mouse and woodchuck model. J Virol 86:9297-9310

91. Kosinska AD, Zhang E, Johrden L, Liu J, Seiz PL et al (2013) Combination of DNA prime-adenovirus boost immunization with entecavir elicits sustained control of chronic hepatitis B in the woodchuck model. PLoS Pathog 9:e1003391

92. Klenerman P, Hill A (2005) T cells and viral persistence: lessons from diverse infections. Nat Immunol 6:873-879

93. Liu J, Zhang E, Ma Z, Wu W, Kosinska A et al (2014) Enhancing virus-specific immunity in vivo by combining therapeutic vaccination and PD-L1 blockade in chronic hepadnaviral infection. PLoS Pathog 10:e1003856

94. Barber DL, Wherry EJ, Masopust D, Zhu B, Allison JP et al (2006) Restoring function in exhausted CD8 T cells during chronic viral infection. Nature 439:682-687

95. Finnefrock AC, Tang A, Li F, Freed DC, Feng M et al (2009) PD-1 blockade in rhesus macaques: impact on chronic infection and prophylactic vaccination. J Immunol 182:980-987

96. Maier H, Isogawa M, Freeman GJ, Chisari FV (2007) PD1:PD-L1 interactions contribute to the functional suppression of virus-specific CD8+ T lymphocytes in the liver. J Immunol 178:2714-2720

97. Velu V, Titanji K, Zhu B, Husain S, Pladevega A et al (2009) Enhancing SIV-specific immunity in vivo by PD-1 blockade. Nature 458:206-210

98. Boni C, Fisicaro P, Valdatta C, Amadei B, Di Vincenzo P et al (2007) Characterization of hepatitis B virus (HBV)specific T-cell dysfunction in chronic HBV infection. J Virol 81:4215-4225

99. Fuller MJ, Callendret B, Zhu B, Freeman GJ, Hasselschwert DL et al (2013) Immunotherapy of chronic hepatitis $C$ virus infection with antibodies against programmed cell death-1 (PD1). Proc Natl Acad Sci USA 110:15001-15006

100. Gardiner D, Lalezari J, Lawitz E, DiMicco M, Ghalib R et al (2013) A randomized, double-blind, placebo-controlled assessment of BMS-936558, a fully human monoclonal antibody to programmed death-1 (PD-1), in patients with chronic hepatitis $\mathrm{C}$ virus infection. PLoS ONE 8:e63818

101. Day CL, Kaufmann DE, Kiepiela P, Brown JA, Moodley ES et al (2006) PD-1 expression on HIV-specific T cells is associated with T-cell exhaustion and disease progression. Nature 443:350-354

102. Penna A, Pilli M, Zerbini A, Orlandini A, Mezzadri S et al (2007) Dysfunction and functional restoration of HCV-specific CD8 responses in chronic hepatitis $\mathrm{C}$ virus infection. Hepatology 45:588-601

103. Petrovas C, Casazza JP, Brenchley JM, Price DA, Gostick E et al (2006) PD-1 is a regulator of virus-specific CD8+ T cell survival in HIV infection. J Exp Med 203:2281-2292
104. Fisicaro P, Valdatta C, Massari M, Loggi E, Biasini E, et al (2010) Antiviral intrahepatic T-cell responses can be restored by blocking programmed death-1 pathway in chronic hepatitis B. Gastroenterology 138:682-693, 693 e681-e684

105. Zhang E, Zhang X, Liu J, Wang B, Tian Y et al (2011) The expression of PD-1 ligands and their involvement in regulation of $\mathrm{T}$ cell functions in acute and chronic woodchuck hepatitis virus infection. PLoS ONE 6:e26196

106. Meng Z, Qiu S, Zhang X, Wu J, Schreiter T et al (2009) Inhibition of woodchuck hepatitis virus gene expression in primary hepatocytes by siRNA enhances the cellular gene expression. Virology 384:88-96

107. Meng Z, Zhang X, Wu J, Pei R, Xu Y et al (2013) RNAi induces innate immunity through multiple cellular signaling pathways. PLoS ONE 8:e64708

108. Zhang X, Hou J, Lu M (2013) Regulation of hepatitis B virus replication by epigenetic mechanisms and microRNAs. Front Genet 4:202

109. Pei R, Qin B, Zhang X, Zhu W, Kemper T et al (2014) Interferon-induced proteins with tetratricopeptide repeats 1 and 2 are cellular factors that limit hepatitis B virus replication. J Innate Immun 6:182-191

110. Chisari FV, Mason WS, Seeger C (2014) Virology. Comment on "Specific and nonhepatotoxic degradation of nuclear hepatitis B virus cccDNA". Science 344:1237

111. Xia Y, Lucifora J, Reisinger F, Heikenwalder M, Protzer U (2014) Virology. Response to Comment on "Specific and nonhepatotoxic degradation of nuclear hepatitis B virus cccDNA". Science 344:1237

112. Heathcote J, McHutchison J, Lee S, Tong M, Benner K et al (1999) A pilot study of the CY-1899 T-cell vaccine in subjects chronically infected with hepatitis B virus. The CY1899 T Cell Vaccine Study Group. Hepatology 30:531-536

113. Dahmen A, Herzog-Hauff S, Bocher WO, Galle PR, Lohr HF (2002) Clinical and immunological efficacy of intradermal vaccine plus lamivudine with or without interleukin-2 in patients with chronic hepatitis B. J Med Virol 66:452-460

114. Horiike N, Fazle Akbar SM, Michitaka K, Joukou K, Yamamoto $\mathrm{K}$ et al (2005) In vivo immunization by vaccine therapy following virus suppression by lamivudine: a novel approach for treating patients with chronic hepatitis B. J Clin Virol 32:156-161

115. Vandepapeliere P, Lau GK, Leroux-Roels G, Horsmans Y, Gane E et al (2007) Therapeutic vaccination of chronic hepatitis B patients with virus suppression by antiviral therapy: a randomized, controlled study of co-administration of HBsAg/AS02 candidate vaccine and lamivudine. Vaccine 25:8585-8597 